University of Nebraska - Lincoln

DigitalCommons@University of Nebraska - Lincoln

Textile Society of America Symposium

Proceedings

Textile Society of America

2020

Stories of Welcome Blanket Makers: Towards a Philosophy of

Craft

Alesia Maltz

Follow this and additional works at: https://digitalcommons.unl.edu/tsaconf

Digitalrt of the Art and Materials Conservation Commons, Art Practice Commons, Fashion Design

Commens, Fiber, Textile, and Weaving Arts Commons, Fine Arts Commons, and the Museum Studies detwerkns

Logo

This Article is brought to you for free and open access by the Textile Society of America at

DigitalCommons@University of Nebraska - Lincoln. It has been accepted for inclusion in Textile Society of America

Symposium Proceedings by an authorized administrator of DigitalCommons@University of Nebraska - Lincoln. 
Published in Hidden Stories/Human Lives: Proceedings of the Textile Society of America 17th Biennial Symposium, October 15-17, 2020. https://digitalcommons.unl.edu/tsaconf/ Copyright $\odot 2020$ Alesia Maltz

doi: $10.32873 /$ unl.dc.tsasp. 0118

\section{Stories of Welcome Blanket Makers: Towards a Philosophy of Craft}

Alesia Maltz

amaltz@antioch.edu

\section{Introduction}

Welcome Blankets is a project undertaken by a community of crafters to bring security blankets to unaccompanied immigrant children. This paper reflects on Welcome Blankets in light of an intriguing discussion that emerged in the TSA 2020 session on the nature, value, and critique of craftivism. Whether or not the Welcome Blankets should be considered a craftivism project, the conference provides an opportunity to step back and reflect on a philosophy of craft and craftivism. This paper sketches three philosophical lenses for critique. From the perspective of the craftsperson, it explores the nature of weaving as a meditative act that brings together opposites. From the perspective of the made object, it employs actor network theory, which encourages the plaiting of weak social ties. The final section introduces ideas from aesthetics to frame the relationships of truth, beauty, and justice. By peering through these three lenses, we may envision a more expansive view of craftivism and craft.

\section{The Story of Welcome Blankets}

In the spring of 2018, when The United Church of Christ in Norfolk, Connecticut created a Maker Space to serve the larger community, I was given a tremendous gift, the opportunity to use a room in the basement of the church. When we opened the Loom Room to free weekly weaving classes, a slow but steady stream of knitters, crocheters, and quilters stopped by. People curious about weaving would come in, perhaps to weave a shot, or to dedicate months to learn the craft. We asked, "Now that we have this wonderful space, what else might we do?"

It did not take long before the scandal broke of our nation's "zero tolerance" immigration enforcement policy, replete with stories of how immigrant children at the US border were being separated from their parents. The Loom Room put out a call by word of mouth asking for security blankets. Yarns, knitting needles and crocket hooks were made available in the Loom Room. The parameters were simple. We requested that the blankets be machine washable and small, since people carrying their worldly belongings don't need to drag along a large blanket. This appealed to craftswomen, who found they could make a two-foot blanket in a night or two. We requested textures that are comforting to little hands and colors that promote healing and celebration. This request enticed frugal New Englanders to use up scraps of material. We requested that each blanket be accompanied by a note. Some people wrote in Spanish. One nineyear old wrote, "Welcome to America. I hope you have a good life." Knitters, crocheters, weavers, and quilters got busy. Blankets started appearing in plastic bags on the doorknob. Others arrived with people and stories about how they were made and why. By word of mouth, a similar group of blanket makers emerged at Notre Dame University. Another group at the UCC 
church in Marlboro NH made blankets and set up a mission trip to deliver them across the southern border to asylum seekers camping out in the cold.

Soliciting blankets was easy. The blanket makers enthusiastically drew together to respond to the needs of the moment. The more difficult task was to find an organization that could get them to the children. Given the impermeable wall of ICE detention centers, the ties between our community and the children at first seemed attenuated.

Finding the way forward was a matter of faith and fate. In the Greek tradition, the Fates are depicted as weavers whose work shapes the lives of humans." Kairos: "... a term that comes from the art of weaving...refers to the brief instant when the weaver may shoot her shuttle through the rising and falling warp threads. A kairos is a penetrating opening in the weaving of cloth, the weaving of time, the weaving of fate." 1 The opening is "a lucky break, a hole in the surrounding cloth. The lucky find is an opportunity, then, a pore or penetrable opening in an otherwise closed design." 2 Two amazing organizations were our lucky break, one steeped in craftivism and the other is social justice. I believe that the enthusiasm of the crafters was key to our lucky find, the small opening that enabled us to get the blankets distributed.

We first reached out to Welcome Blankets. This was a project led by Jayna Zweiman, a wellknown craftivist who co-designed the Pussy Hats action. Welcome Blankets was her response to Trump's call for a Border Wall. "Imagine if the massive distance of this wall was reconceptualized and re-contextualized not to divide, but to include. Instead of a wall, a concrete line, to keep people out, what if lines of yarn became 3,500,640 yards of blankets to welcome people in?"3 The 3200 blanket goal was quickly reached, and contributions were displayed in the Smart Museum of Art at the University of Chicago. The makers composed notes welcoming newly arrived immigrants, and after the show, blankets and their accompanying notes were distributed to refugees and immigrants in resettlement communities throughout the US.

I asked Zweiman if she knew of anyone who was accepting small blankets for children at the border. "What a good idea!" she said. She responded at the pace of an activist who knows the ins and outs of organizing. Within 24 hours of my email, she had established a web page, Welcome Blankets on Call, which solicited small blanket donations for the border. She also found a contact in Phoenix, Arizona. Once ICE had decided that it was too dangerous to drop families off at the Phoenix bus stop, they asked the city of Phoenix to open a temporary shelter for families released from the ICE facilities. Within a couple of months, we had created 110 blankies and 75 hand knit dolls, as well as toiletries and socks for 100 children. We blessed them on the church alter, and shipped them out.

Although delighted that they were reaching the children, we still hoped to get the blankets directly to children still within the system. "Maybe you could give them to our children," said Dr. Sasha Akins, an Environmental Studies professor at Loyola University in Chicago who

\footnotetext{
${ }^{1}$ Lewis Hyde, Trickster Makes this World (New York: Farrar, Strauss and Giroux, 1998), 133.

${ }^{2}$ Lewis Hyde, 133.

${ }^{3}$ Welcome Blankets https://www.welcomeblanket.org/ and Welcome Blankets on Call https://www.welcomeblanket.org/oncall is the page Zweiman created to funnel blankies to the children in Arizona as they are being released from ICE.
} 
volunteers at the Heartland Alliance. The Alliance prides itself on being one of the world's leading antipoverty organizations. It is a human rights organization focused for the last 130 years on equity and justice for the poor, the isolated, and the displaced. Its staff comes from fifty-one countries and incudes translators who speak thirty foreign languages. ${ }^{4}$ It runs the National Immigrant Justice Center and provides a humane shelter for unaccompanied migrant youth and refugees. Heartland unites unaccompanied youth with their families, provides educational programs and medical care for them, accommodates children at its transitional housing and residential facilities, and proffers immigrant services after the children leave their immediate care. The week I called to discuss a partnership, demonstrators in front of their building falsely accused the Heartland Alliance of keeping children in cages. Maria Kenney assured me that ICE has nothing to do with the Alliance's programs. Within 72 hours of arriving in Chicago, unaccompanied minors are transferred from ICE custody to the HHS Office of Refugees and Resettlement and then to Heartland. The main objective at Heartland is family unification, although they occasional do host unaccompanied children with long-term medical needs. Given the cold winters in Chicago, and the ages of the children, we added handwoven scarves to a bale of blankets, and sent them to the Heartland Alliance.

We are very grateful to both Welcome Blankets, a craftivism project, and the Heartland Alliance, a social services organization, for providing bridges between the blanket makers and the children.

\section{Craftivism and Critique}

The 2020 TSA meeting section on craftivism was punctuated by an intriguing discussion about the meaning and value of craftivism. The relationship between craft and activism long predates the term - the Aids Quilt, William Morris, and handweaving in the Indian Independence Movement come to mind. The political focus of craftivists has run the gamut from elections (Pussy Hats) to resource extraction (Knitting Nannas Against Gas). Along with the rapid rise in craftivism entrepreneurs, an academic cottage industry has sprung up proffering critiques of craftivism. A Google Scholar search in January of 2021 highlighted 714 academic articles, books and dissertations on craftivism. While a few critiques examine implications of craft for activism, the majority focus on identity-based politics, including: virtue signaling and performative allianceship; second wave white feminists and lifestyle activism; neoliberalism and neodomesticity; intergenerationality and intersectionality; commodification and erasure; gender and race normativity; and above all, White privilege.

There is no denying that, at its worst, craftivism can be accused of any of these criticisms. Any single and unifying object - such as pussyhats—will not feel inclusive to some; unity is elusive. Although we were not trying to be craftivists, our own project fell short of the goals of craftivism. Zweiman's On-Call component of the Welcome Blanket project, which the Loom Room sparked and participated in, was not a design intervention to produce social change. It was not a political action, but a way of reaching out to acknowledge the dignity of the children. It was not "othering;" we created things for unaccompanied minors in the same way we do children in our own community. It was not an opportunity for group discussions, as Zweiman proposed. She

\footnotetext{
${ }^{4}$ Maria Kenney, personal communication, 19 February 2020.
} 
developed a set of workshop questions, and a process by which people involved in the project could reflect with each other about the meaning of immigration. The women connected with the Loom Room did not wish to gather for such a discussion, did not wish to be interviewed individually, and did not necessarily frame their work as political resistance. Our project was a way to communicate through handmade objects when people were blocked from speaking to each other because of bureaucratic and international boundaries. It was a means to transmute despair through beauty. It was practical; both Democratic and Republican grandmas know that little ones traveling needed their security blankies.

The well-worn template used to critique craftivism does not hold up when applied to the Welcome Blankets project at the Loom Room. A small, seemingly homogenous group of White, liberal, middle-class women harbored significant diversity. In the Loom Room, conversations spontaneously emerged that revealed we were far from homogenous. The people involved in the project, while mostly retired or semi-retired, range from age nine to ninety. They hold all imaginable political views. They're first generation immigrants and descendants of the Mayflower, people who live in wealthy summer "cottages" and people who live in assisted housing. They are yarn ("stash") donors and people who come to the Loom Room--like they come to the Church's Food Pantry--to acquire needed craft supplies for their families. They are White and Native American, gay and straight, concentration camp survivors and survivors of indentured servitude, church deacons and atheists, second wave feminists and anti-feminists, professional artists and rank amateurs who had never been involved with textile crafts before, climate change deniers and climate activists who identify migration as an urgent consequence of the climate crisis. ${ }^{5}$ Our most generous and dedicated makers, The Norfolk Knitters, were not looking for a project aimed at people far afield, but instead took time from their local project that served children in need in the local community. The unexpected conversations in the Loom Room revealed these hidden identities. The diversity of people associated with the Loom Room suggests that identity politics will only take us so far as an explanatory framework for, or critique of, craftivism.

On the sticky wicket of motivation, perhaps people would classify this as a craftivism project, especially since we were involved with Welcome Blankets, or perhaps not. While I personally do not object to the term, and maintain neutrality on the classification issue, I doubt whether anyone who donated blankies self-identified as craftivists, or even heard of the term. Collectively, ours was not explicitly designed as a craftivism project or a political message to Melania Trump's infamous jacket ("I really don't care, do you?"). Although we most certainly do care, our focus of attention was on innocent children caught in other peoples' political dramas. The Trump supporters affiliated with the Loom Room, like the rest of us, kept their eyes on the children.

Reflecting on Welcome Blankets in light of the craftivism has led me to a scrutiny of critique itself. Shawn Wilson, an inspiring indigenous scholar interested in decolonizing methodologies,

\footnotetext{
5 The Nobel Prize winning economist, Amartya Sen, argues that there is seldom a single identity to point to; characters play many roles simultaneously. "The same person can, for example, be a British Citizen, of Malaysian origin, with Chinese racial characteristics, a stockbroker, a non-vegetarian, an asthmatic, a linguist, a bodybuilder, a poet, an opponent of abortion, a bird-watcher, an astrologist, and one who believes that God created Darwin to test the gullible." Amartya Sen, Identity and Violence: The Illusion of Destiny (New York: W.W. Norton, 2006), 24.
} 
writes, "Criticizing or judging would imply that I know more about someone else's work and the relationships that went into it than they do themselves." The sociologist of science, Bruno Latour, argues that critique has run its course and inquires whether we should, "bring the sword of criticism to criticism itself." "Latour, who has been identified as the most quoted living scholar, envisions a societal shift from debunking to protecting and caring, and advocates for a turn from matters of fact to matters of concern.

I aspire to generative approaches that enable us to create things of beauty as a way of responding to matters of concern. Can we undertake more appreciative forms of inquiry, and develop a nuanced philosophical framework about the relationship between craft and activism? At "Feverish World," a conference on art and climate change, Latour spoke about how we must metabolize the difficult issue of climate change through science, politics, and art simultaneously. He is collaborating with visual artists, a theatre troupe, and a group of dancers to reconceptualize climate change. ${ }^{8}$ Torkwase Dyson, a Black activist and artist who also served as a keynote at the Feverish World conference, encouraged us to produce art that:
a) invigorates by encouraging
b) identifies dormant potential
c) identifies hidden beauty ${ }^{9}$

Dyson's directive is an extraordinary framework for critique. The next three sections sketch a philosophical approach to craft and political action inspired by Dyson. Section III of this paper examines how to "invigorate by encouraging" by sketching a phenomenology of weaving. The fourth section draws on Bruno Latour's theories of the social to identify the dormant potential of craft to "plait weak ties;" and the final section examines the how we might enlist Beauty in rejuvenating its weary sisters, Truth and Justice.

\section{Invigorate by Encouraging}

Every artform and every craft teaches us certain things about how to craft ourselves into becoming better human beings; weaving is no exception. The Loom Room attracts not only experienced textile craft professionals, but also but hobbyists, curious youth and adults with no previous experience of textile craft.

Despite the wide range of expertise, people are encouraged to take risks. Consider the child in our community who allows his security blankie to be cut up and shared with children he doesn't know. Consider the child's grandmother who said, "I listen to the news and get so upset! Then I remember, pick up my knitting needles and think of the children." Both grandmother and grandson were engaged in acts of metabolizing, or transforming, sorrow or anger into something

\footnotetext{
${ }^{6}$ Shawn Wilson, Research Is Ceremony: Indigenous Research Methods (Black Point, N.S.: Fernwood Pub., 2008), 43.

${ }^{7}$ Bruno Latour, "Why Has Critique Run out of Steam? From Matters of Fact to Matters of Concern," Critical Inquiry: 30 (Winter 2004), 227.

${ }^{8}$ Bruno Latour, Facing Gaia (Medford MA: Polity Press, 2017).

9 Torkwase Dyson, "Water as Geography, Hand as Vessel, Black as Liquid," Feverish World Symposium, 22 Oct. 2018.
} 
beautiful. Tim Ingold likens craft to medieval alchemy. He talks about the "ongoing binding together" that creates coherence between the materials and the maker. ${ }^{10}$

In the Loom Room we bind together different community members who don't usually spend time together-elders and youth, friends and strangers, hobbyists and professional artists. Everyone is welcome and encouraged not only to learn the technique and process, but also be creative. Irrespective of one's level of experience, the phenomenological experience of weaving can become movement meditation, choreography, spiritual development, or psychological healing. When you're in "the flow," the place where you're doing what you enjoy, you may enter a place of intense concentration. You could lose yourself to the weaving and your sense of time might get distorted. ${ }^{11}$ Repetitive actions that both challenge you and requires skill can transport you into a state of flow. Weave till your heart is content. Get the rhythm and follow the thread as if were a path. In a state of flow, the mind opens, cleared of thought.

In the weaving process, the smooth movements between the back beam and the breast beam, between castle and shed, between selvedge and selvedge, between the opening and closing of the shed as the weft passes through — allows for the integration of opposites. The weaver's feet enact an elaborate dance to unleash the pattern encoded in the castle, while her hands glide between the weft and the beater. Together, row by row, they create harmony and unity.

The process of weaving is about taking individual unrelated strings, and bringing them into relationship with each other. Weaving is about relationship, the interpenetration of opposites. The Pointillist painters and generations of weavers before them were masters of conversations of color. New and fleeting colors emerge by juxtaposition. Texture, which can also alter color, is revealed by the in-between spaces, the shadows and hills, what artists call the negative and positive space. In the mystical Christian traditions, this idea of negative space is encapsulated in ideas about the via positive and the via negative.

As a spiritual practice, the weaver sits at the loom as a conduit between the axis mundi and the earthly journey. As a physical practice, the weaver takes individual, separate and unrelated strings, and brings them into relationship with each other. The process of weaving as a spiritual practice can become a form of prayer, bringing opposites together to create whole cloth. The cloth is not actually made whole until it is taken off the loom and fulled. Today, many people full a cloth by tossing it in the washing machine; in many traditional societies, fulling was a social event that felted together both the woven web and the community. Finally, you give the weaving away. The process is not complete until the product is given away to loved ones or strangers who then weave the cloth into their own lives.

\footnotetext{
${ }^{10}$ Ingold, Tim. “Thinking Through Making.” Institute for Northern Culture Oct 31, 2013. https://www.youtube.com/watch?v=Ygne72-4zyo.

Reflecting on David Guss's anthropological study of the Yekuana basket-makers in present day Venezuela, Ingold observes, "The master craftsman in this society, a person accredited with exceptional wisdom, "not only weaves the world when making a basket, but in everything he does.",

${ }^{11}$ The idea of flow, developed by the psychologist Mihaly Csikszentmihalyi, is summarized in his TED talk, "Flow: The Secret to Happiness," February, 2004. https://www.ted.com/talks/mihaly_csikszentmihalyi_flow_the_secret_to_happiness?language=en\#t-1119369.
} 
Who or what needs to be brought together? There are volumes to be said about the phenomenology of weaving, but in this brief sketch, weaving is a form of meditation. Weavers construct whole cloth by integrating opposites. They transform tension into beauty.

How can such an act of meditation be related to social justice? In short, weaving provides a tactile experience of tension and teaches the weaver how to metabolize tension. Tension is a sign of life and an essential tool for weaving. The weaver learns about how to hold an even tension when putting on the warp. In an ideal warp, every string has the same tension. This democratization of tension is essential to creating beauty. The weaver is not releasing emotional tension, but maintain such an even tension that all tension is diffused. From the ongoing negotiation between the opposites of warp and weft, weavers employ that tension to unite opposites. Through the process of constant, slow, repetitive rhythm, the weaver learns how to hold and release the tensions which, when transformed, creates fabric that shimmers on the loom. The weaver responds to all these places of opposition with a consistent even tension-in the beating of the reed, in the selvedges, and in the tension on the warp threads. Weaving is a practice that transforms tension from a destructive force into creative energy.

Dr. Martin Luther King said creating non-violent tension is necessary for the kind of growth that arouses what Lincoln called "the better angels of our nature." In his speech, "Remaining Awake Through a Great Revolution," King said:

All I'm saying is simply this: that all mankind is tied together; all life is interrelated, and we are all caught in an inescapable network of mutuality, tied in a single garment of destiny. Whatever affects one directly, affects all indirectly. For some strange reason I can never be what I ought to be until you are what you ought to be. And you can never be what you ought to be until I am what I ought to be - this is the interrelated structure of reality.... And by believing this, by living out this fact, we will be able to remain awake through a great revolution. ${ }^{12}$

Can you imagine a better practice to train and renew activists than have them create whole cloth?

\section{Dormant Potential: Plaiting Weak Ties}

Sue Williams, who teaches spinning in the Loom Room, reminds us that the wheel sounds like a heartbeat and that the pace of the wheel-no matter how fast - matches the pace of the heart of the spinner. ${ }^{13}$ Spinning serves as both a metaphor and practice. Spinners break materials apart in order to join the parts up together in correspondence. In his talk, "Thinking Through Making,"

\footnotetext{
${ }^{12}$ Rev. Dr. Martin Luther King, Jr., "Remaining Awake Through a Great Revolution," Commencement Address for Oberlin College, June 1965, Oberlin Ohio. Oberlin College Archives. https://www2.oberlin.edu/external/EOG/BlackHistoryMonth/MLK/CommAddress.html

At the King archives at Stanford University the line before the last is phrased slightly differently: "This is the way God's universe is made; this is the way it is structured."

https://kinginstitute.stanford.edu/king-papers/publications/knock-midnight-inspiration-great-sermons-reverendmartin-luther-king-jr-10

${ }^{13}$ Sue Williams, personal communication, January, 2019.
} 
the anthropologist Tim Ingold talks about a rope as correspondence of parts. The twist of each strand of the rope is contrary to the torque of the rope as a whole, yet there is harmony and coherence in the structure. He reminds us that the syllable "arm" in Greek, meaning "to join," is the root of the word "harmony."14

Bruno Latour also draws on metaphors of rope. He sees society not as a noun but as a verb; it is the constant creation of networks of people and things. Modern societies, he says, "cannot be described without recognizing them as having a fiberous, thread-like, wirey, stringy, ropy, capillary character..."15 Latour says, "Strength does not come from concentrations, purity and unity, but from dissemination, heterogeneity, and the careful plaiting of weak ties." 16

Textile projects are uniquely positioned to plait weak ties. With all the blankies showing up on the Loom Room doorknob, I faced the challenge of finding a way to get them through the impenetrable walls of ICE facilities directly to the children. I failed. That was too weak a tie to plait. "The way will open," I kept thinking as I sat and wove, and it eventually did open. Just as weak ties within our community were plaited together through the act of making gifts of security blankets, weak ties between the crafters and the detained children were mediated by two amazing organizations who helped us disseminate these gifts.

In our consumeristic and object-drenched society, gift giving is an agent of social cohesion, a tie that binds us together. Christa Tippet describes this in her discussion of agape. She defines agape as kindness, or the type of love that might be given to a stranger or neighbor. It is love embodied, a kind of practical compassion that identifies the work that can be done, and does it. ${ }^{17}$ Tippitt says that these expressions of kindness to strangers can bring joy to all involved, a sense of communion, of belonging together. Tippitt remarks:

Some of us have literal work to do in knowing our neighbors, being present as neighbors. I do want to glorify this with the word love-such relationships are the basic connective tissue of common life. It's worth repeating that as love crosses the chasms between us, it likewise brings them into relief. The challenge of standing before open ruptures in civic life is matched, and complicated, by the challenge of standing hospitably before those who offend and harm and drive us crazy in an everyday way.... I use the word hospitably with intention. Hospitality is a word that shimmers softly. It offers itself as an accessible entry point to love in action. ${ }^{18}$

A Welcome Blanket is a small, but not insignificant, way of being present to our neighbors, or neighbors to be. Through the Welcome Blanket project, the Loom Room community expanded our understand of who "we" are, and how these immigrant children are a part of us. We were drawn into a wider self, and developed a deeper sense of belonging.

\footnotetext{
${ }^{14}$ Ingold, Tim. "Thinking Through Making.” Institute for Northern Culture, Oct 31, 2013.

https://www.youtube.com/watch?v=Ygne72-4zyo

${ }^{15}$ Bruno Latour, “On Actor Network Theory: A Few Clarifications 1/2 Nettime, 1997. https://www.nettime.org/ListsArchives/nettime-1-9801/msg00019.html This idea was expanded on in his book, Reassembling the Social: An Introduction to Actor-Network-Theory, Latour, Bruno, Oxford University Press, 2005.

${ }^{16}$ Latour, 1997.

${ }^{17}$ ChristaTippitt, Becoming Wise: An Inquiry into the Mystery and Art of Living (New York: Penguin, 2017), 123

18 Tippitt, 137.
} 
At the heart of craftivism is the belief that craft is a viable, if humble, response to the insurmountable issues of our times, such as colonialism, racism, sexism, resource extraction, and climate change. Although climate change might seem a weak tie to textile craft or craftivism, it is in plaiting these weak ties that creativity is sparked. How might textile artists and craftspeople become involved, as this project is, in climate resilience? My long-standing concern stems from work as an Environmental Studies professor focusing on climate change and environmental justice. Because of climate change, people, plants, and animals are on the move; we all are becoming climate migrants. ${ }^{19}$ Making blankies for migrant children is a small trickle in a stream of climate resilience. For environmental refugees experiencing policies and practices of exclusion, welcome blankets are a first response for a crisis demanding first responders. What else might textile artists and craftspeople do? How can we interpret the climate crisis through textiles, create new designs that serve those displaced by climate change and those who cause it, help refugees maintain and renew their own textile traditions, or chart--as the Tempestry

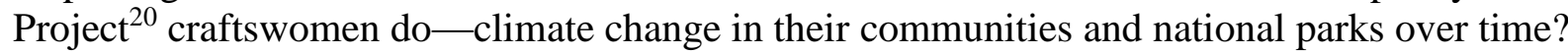

Living in a time of tremendous fragmentation, how do we awaken the dormant potential to work together? Craftspeople know how to take the inward turn to create whole cloth; activists know how to take the outward turn to effect social change. Whether we deem ourselves to be craftivists or not, craftivism reminds us that craftspeople have an open invitation to engage in pleating weak ties between their craft and the existential issues of our day.

\section{Hidden Beauty: Truth, Beauty, Justice}

The relationship between Truth, Beauty, and Justice has been framing Western thinking since the time of Plato. At the beginning of the last century, Yeats was still able to proclaim, "Beauty is truth, truth beauty - That is all ye know on earth, and all ye need to know." ${ }^{21}$ In classical Greece, the Transcendentals of Beauty, Truth and Justice walked together. Today we no longer dare to believe in beauty; some sneer "... at her name, as if she were the ornament of a bourgeois past." 22 In a world of Truth and Post-Truth, it seems that Truth and Justice are hammering at each other while Beauty stands quietly in the middle. Beauty's ability to step back is her strength, says the theologian Hans urs von Balthasar:

"Beauty is the disinterested one, without which the ancient world refused to understand itself, a word which both imperceptibly and yet unmistakably bid farewell to our new world, the world of interests, leaving it to its own avarice and sadness.... Our situation today shows that beauty demands for itself as much courage as truth and goodness, and she will not allow herself to be banned from her two sisters..."23

\footnotetext{
${ }^{19}$ Given current trends, Connecticut is projected have the climate of South Carolina by the end of this century. Climate Change State Profiles, Connecticut- UMass Amherst Report CSRC https://www.geo.umass.edu > CT_ClimateReport_CSRC

${ }^{20}$ Tempestry, https://www.tempestryproject.com/

${ }^{21}$ O'Donahue, 57.

${ }^{22}$ Gregory Wolfe, "The Wound of Beauty," https://imagejournal.org/article/the-wound-of-beauty/

${ }^{23}$ O’Donohue, 4.
} 
Beauty, von Balthasar believes, is disinterested in the sense that, "it has no agenda. Beauty can sail under the radar of our anxious contention over what is true and what is good, carrying along its beam a ray of the beatific vision." ${ }^{24}$ Craftivism is a modest experiment to encourage Beauty to resume her rightful place between Truth and Justice.

Erick Olsen, The UCC minister at the Norfolk church that hosts the Loom Room, defines justice beautifully as, "the restoration and healing of broken people and systems." "Beauty is the sister of all that is broken, damaged, stunted, and soiled," 25 says O'Donohue, adding, "when we hold beauty and truth together, truth will always have a sense of compassion and gentleness." 26 This encapsulates the relationships among the three Transcendentals. O'Donohue suggests that Beauty invites us:

...to engage the infinite design that shapes our days and dreams. She does not force on us any manufactured coherence toward which we must falsely strain; this is the diametrical opposite of all forms of fundamentalism. She invites us to surrender so that we can participate in the forming of a new and vital coherence that is native to our desire. In such unsheltered and uncertain times we yearn for this order and coherence... ${ }^{27}$

\section{Conclusion}

The Welcome Blankets project enabled the Loom Room community to weave together local concerns with hopes for international justice. The Welcome Blankets project became both a response to truth of the children's plight and a pathway to poetic justice. While there is are numerous reasons to commend or critique craftivism, this paper claims that critique at its best invigorates by encouraging, identifies dormant potential, and identifies hidden beauty. Craftivism is a clever and fashionable term, but the length of its shelf life has yet to be determined. Yet it compels us to ask a compelling question: who or what needs to be brought together? In a society being increasingly propelled by matters of concern, we each choose whether to bring together craft and action. How to do that is perhaps the challenge of craftivism. Restoring Beauty to its rightful place between Truth and Justice will remain a challenging question for craftspeople.

\footnotetext{
${ }^{24}$ Wolfe.

${ }^{25}$ O’Donohue, Beauty, 194.

${ }^{26}$ O’Donohue, 54.

${ }^{27}$ O’Donohue, 8.
} 


\section{Bibliography}

Climate Change State Profiles, Connecticut- UMass Amherst Report CSRC https://www.geo.umass.edu >CT_ClimateReport_CSRC

Csikszentmihalyi, Mihaly. "Flow: The Secret to Happiness," TED Talk, February 2004.

https://www.ted.com/talks/mihaly_csikszentmihalyi_flow the secret_to_happiness?language=en \#t-1119369

Dyson, Torkwase. "Water as Geography, Hand as Vessel, Black as Liquid," Feverish World Symposium, 22 Oct. 2018.

Hyde, Lewis. Trickster Makes This World: Mischief, Myth, and Art. New York: Farrar, Strauss and Giroux, 1998.

Ingold, Tim. "On Weaving a Basket," The Perception of the Environment: Essays on Livelihood, Dwelling and Skill. New York: Routledge, 2000.

Ingold, Tim. “Thinking Through Making.” Institute for Northern Culture Oct 31, 2013 https://www.youtube.com/watch?v=Ygne72-4zyo.

Kenney, Maria. Personal communication, 19 February 2020.

King, Rev. Dr. Martin Luther Jr., "Remaining Awake Through a Great Revolution," Commencement Address for Oberlin College, June 1965, Oberlin Ohio. Oberlin College Archives. https://www2.oberlin.edu/external/EOG/BlackHistoryMonth/MLK/CommAddress.html

Latour, Bruno. “On Actor Network Theory: A Few Clarifications 1⁄2 Nettime, 1997. https://www.nettime.org/Lists-Archives/nettime-1-9801/msg00019.html

Latour, Bruno. "Why Has Critique Run out of Steam? From Matters of Fact to Matters of Concern," Critical Inquiry 30 (Winter 2004).

Latour, Bruno. Reassembling the Social: An Introduction to Actor Network Theory. New York: Oxford University Press, 2005.

O’Donohue, John. Beauty. New York: Harper Collins, 2004.

Sen, Amartya. Identity and Violence: The Illusion of Destiny. New York: W.W. Norton, 2006.

The Tempestry Project. https://www.tempestryproject.com/about/

Tippitt, Christa. Becoming Wise: An Inquiry into the Mystery and Art of Living. New York: Penguin Press, 2017. 
Williams, Sue. Personal communication, January, 2019.

Wilson, Shawn. Research Is Ceremony: Indigenous Research Methods. Black Point, N.S.: Fernwood Pub., 2008, 43.

\section{Acknowledgements}

Thank you to TSA for this opportunity to present our work. I also want to thank the craftspeople of Northwestern Connecticut who enthusiastically took up the call for blankets, Sue Williams (my girl Tuesday) who works with me in the Loom Room side by side, Erick Olsen and Kelly Kandra Hughes at the UCC Church of Norfolk for their support and facilities, Bob Bull who got the looms working, Bill and Ginny Eckert who opened the door to possibility of the Loom Room, Janya Zweiman at Welcome Blankets and Maria Kenney at the Heartland Alliance who paved the way between the Loom Room and the children, and Antioch University for having the vision to support the arts and humanities as part of an Environmental Studies curriculum. May the children heal and thrive. 